\title{
UPAYA PENINGKATAN PENGETAHUAN MASYARAKAT DALAM RANGKA PENCEGAHAN DAN PENANGGULANGAN DBD DI DESA DLINGO, MOJOSONGO, BOYOLALI
}

\author{
Novena Yety Lindawati'1), Lusia Murtisiwi ${ }^{1)}$, Tesia Aisyah Rahmania2), Prashinta Nita \\ Damayanti ${ }^{1}$, Feransiska Marentina Widyasari ${ }^{1)}$
}

\begin{abstract}
1)Program Studi S1 Farmasi, Sekolah Tinggi Ilmu Kesehatan Nasional, Surakarta, Jawa Tengah, Indonesia 2)Program Studi Ilmu Farmasi, Fakultas Farmasi Militer, Universitas Pertahanan, Bogor, Jawa Barat, Indonesia
\end{abstract}

Corresponding author :Novena Yety Lindawati

E-mail : novena_yl@yahoo.com

Diterima 13 Maret 2021, Direvisi 06 April 2021, Disetujui 07 April 2021

\begin{abstract}
ABSTRAK
Penyakit Demam Berdarah Dengue (DBD) merupakan penyakit menular yang disebabkan oleh virus dengue. Virus ini masuk ke dalam tubuh melalui gigitan nyamuk genus Aedes. Penyakit DBD ditandai dengan demam tinggi secara terus menerus selama 2 hingga 7 hari dan disertai pendarahan serta shock yang jika tidak segera mendapat penanganan dapat menyebabkan kematian. Pengabdian masyarakat ini bertujuan untuk meningkatkan pengetahuan masyarakat mengenai penyakit DBD dalam rangka pencegahan dan penanggulangan penyakit DBD. Metode yang digunakan adalah ceramah dan diskusi. Penyuluhan dilakukan melalui penyampaian materi terkaitpenjelasan mengenai tanda dan gejala DBD, solusi pencegahan DBD secara alami dengan memanfaatkan bahan alam yang berada disekitar lingkungan, serta pemberantasan jentik-jentik nyamuk menggunakan ABATE.Evaluasi keberhasilan kegiatan pengabdian masyarakat ini dilakukan dengan metode pretest dan posttest. Selain itu juga dilakukan survey kepuasan terhadap kegiatan pengabdian masyarakat melalui pengisian kuesioner oleh peserta.Hasil pengabdian masyarakat menunjukkan adanya peningkatan pengetahuan peserta mengenai pengetahuan dan pencegahan terhadap penyakit DBD. Data hasil pretest menunjukkan yang semula memiliki nilai rata- rata sebesar 75 naik pada hasil nilai postest dengan rata-rata nilai 100 . Hasil evaluasi terhadap tingkat kepuasan peserta kegiatan pengabdian yang dilaksanakan menunjukkan $69,2 \%$ peserta menyampaikan tema yang diambil baik sekali, $26,67 \%$ menyatakan baik dan $2,92 \%$ menyatakan cukup.
\end{abstract}

Kata kunci: penyuluhan; DBD; Boyolali.

\begin{abstract}
Dengue Hemorrhagic Fever (DHF) is a disease caused by the dengue virus. Dengue virus enters the body through the bite of the Aedes mosquito. This community service programs aims to increase knowledge about DHF in the context of preventing dengue disease. The methods used are counseling and discussions. Counseling is carried out through the explanation about signs and symptoms of dengue fever, natural DHF prevention solutions by natural plants, and eradicating mosquito larvae using ABATE. Evaluation of community service activities is carried out using the pretest and posttest methods. In addition, survey of the satisfaction of this program was also conducted through filling out questionnaires by participants. The results of community service showed an increase in participants knowledge of sign, syomptoms and prevention of dengue disease, as indicated by an increase in post test value from 75 to 100.The results of the evaluation of the satisfaction levels of the participants in the program showed $69.2 \%$ of participants said it was very good, $26,67 \%$ said it was good, and $2,92 \%$ said it was good enough.
\end{abstract}

Keywords: counseling; DHF; Boyolali.

\section{PENDAHULUAN}

Penyakit demam berdarah dengue atau yang disingkat sebagai DBD adalah penyakit demam akut yang disebabkan oleh virus dengue (Sukohar, 2014). Virus ini masuk ke peredaran darah manusia melalui gigitan nyamuk dari genus Aedes, misalnya Aedes aegypti atau Aedes albopictus (Kusuma \& Sukendra, 2016). Penyakit ini ditandai dengan demam tinggi secara terus menerus selama 2 hingga 7 hari dan disertai pendarahan serta shock yang jika tidak segera mendapat penanganan dapat menyebabkan kematian (Candra, 2010; Misnadiarly, 2009). 
Penyakit demam berdarah ditemukan di daerah tropis dan subtropis di berbagai belahan dunia. Perubahan iklim, cuaca dan kelembaban adalah faktor resiko terjadinya kasus DBD (Lisiswanti et al., 2015). Pada saat pergantian musim dan musim penghujan penyakit demam berdarah dengue (DBD) sangat mewabah, termasuk di Boyolali. Menurut data Profil Kesehatan Kabupaten Boyolali tahun 2019 jumlah kasus DBD tahun 2019 mengalami kenaikan drastis dibanding tahun 2018 yaitu sebesar 130 kasus (Dinas Kesehatan Kabupaten Boyolali, 2019).

Masyarakat seringkali belum mengetahui bahwa penyakit DBD tergolong dalam penyakit menular. Padahal virus dengue ini dapat menular dari orang yang satu ke orang yang lain melalui gigitan nyamuk Aedes.

Nyamuk Aedes aegeptydan Aedes albopictus adalah nyamuk yang hidup di tempat penampungan air di pemukiman warga (Tampi et al., 2013). Kasus DBD ini dapat dicegah dengan cara memutus daur hidup dari nyamuk Aedes tersebut. Daur hidup nyamuk Aedes dapat diputus dengan cara membersihkan tempat penampungan air di rumah maupun di lingkungan sekitar rumah dan pemberantasan sarang nyamuk (PSN). Pemberantasan sarang nyamuk dapat dilakukan dengan membunuh jentik-jentik nyamuk menggunakan ABATE. ABATE merupakan pestisida dengan bahan aktif Temephos (Yulidar \& Hadifah, 2014). ABATE ini aman digunakan dalam tempat penampungan air asal dalam dosis yang tepat.

Upaya pencegahan dan penanganan DBD dapat dilakukan dengan cara memanfaatkan tanaman herbal yang ada di sekitar kita. Penelitian sebelumnya menyatakan ada beberapa tanaman yang bermanfaat untuk membantu mengatasi DBD antara lain buah dan daun jambu biji, sambiloto, daun pepaya dan sebagainya (Muharni et al., 2013; Prasetio, 2015). Mekanisme tanaman tersebut bermacam-macam, antara lain sebagai antivirus dan meningkatkan kadar trombosit dalam darah. Selain untuk penanganan DBD, ada juga tanaman yang bermanfaat untuk pencegahan DBD karena mengandung aroma yang tidak disukai nyamuk. Sebagai contoh adalah tanaman serai yang mengandung minyak atsiri dengan zat aktif geraniol dan sitronelol sehingga dapat digunakan sebagai penolak nyamuk (Saptawati et al., 2017).

Pengabdian masyarakat melalui kegiatan penyuluhan ini bertujuan untuk menambah wawasan dan pengetahuan masyarakat mengenai tanda dan gejala penyakit $\mathrm{DBD}$, pencegahan penyakit $\mathrm{DBD}$ dengan pemberantasan sarang nyamuk menggunakan ABATE serta pemanfaatan tanaman herbal di sekitar kita untuk pencegahan maupun penanganan penyakit DBD.

\section{METODE}

Program pengabdian masyarakat dilaksanakan pada hari Minggu, 1 Maret 2020. Pelaksanaan program pengabdian kepada masyarakat dalam rangka upaya peningkatan pengetahuan masyarakat dalam rangka pencegahan dan penanggulangan DBD Di Desa Dlingo Kecamatan Mojosongo Kabupaten Boyolali. Peserta kegiatan adalah ibu-ibu PKK desa Dlingo Kecamatan Mojosongo Kabupaten Boyolali sejumlah 31 peserta. Metode yang digunakan dalam pengabdian masyarakat ini adalah ceramah dan diskusi. Penyuluhan dilakukan melalui penyampaian materi terkait penjelasan mengenai tanda dan gejala DBD, solusi pencegahan DBD secara alami dengan memanfaatkan bahan alam yang berada disekitar lingkungan, serta pemberantasan jentik-jentik nyamuk menggunakan ABATE. Dalam pelaksanaannya kegiatan penyuluhan dibagi menjadi beberapa tahap yaitu:

1. Pretest

Pada tahapan ini peserta diberikan pertanyaanpertanyaan seputar topik yang akan disampaikan dalam penyuluhan. Pretest bertujuan untuk mengetahui sejauh mana pengetahuan awal peserta mengenai DBD.

2. Penyampaian Materi

Kegiatan yang kedua adalah pelaksanaan penyuluhan mengenai DBD oleh pemateri dengan rincian sebagai berikut:

Tabel 1. Rincian Pelaksanaan Penyuluhan

\begin{tabular}{ccc}
\hline Waktu & Materi & Pemateri \\
\hline $\mathbf{1 3 . 3 0}$ & Tanda dan gejala & Apt. Lusia \\
$\mathbf{1 4 . 0 0}$ & DBD & Murtisiwi, S. \\
& & Farm., M. \\
& & Sc. \\
\hline $\mathbf{1 4 . 0 0 -}$ & Solusi Pencegahan & Apt. Novena \\
$\mathbf{1 5 . 0 0}$ & DBD secara Alami & Yety \\
& & Lindawati, S. \\
& & Farm., M. \\
& & Sc. \\
\hline $\mathbf{1 5 . 0 0 -}$ & Pemberantasan & Tesia Aisyah \\
$\mathbf{1 6 . 0 0}$ & Jentik Nyamuk & Rahmania, \\
& dengan ABATE & S. Si., M. \\
& & Pharm. Sci.
\end{tabular}

Setelah tahapan penyampaian materi dilakukan diskusi dan tanya jawab antara pemateri dan peserta kegiatan.

3. Monitoring dan Evaluasi

Pada akhir rangkaian kegiatan dilakukan monitoring dan evaluasi dengan pelaksanaan posttest untuk melihat ada tidaknya 
peningkatan pengetahuan dari peserta pengabdian serta pemberian kuesioner untuk melihat kepuasan peserta terhadap kegiatan pengabdian ini.

\section{HASIL DAN PEMBAHASAN}

Pelaksanaan penyuluhan dilaksanakan dalam 3 segmen. Kegiatan ini dikemas dalam format Talk Show dengan materi pertama yang berisikan pengertian DBD, penyebab DBD, cara penularan, ciri-ciri nyamuk Aedes aegypti, fase demam jika sudah terkena DBD, dan tempat berkembang biak nyamuk dan PSN. Segmen kedua berisi materi berupa penjelasan mengenai solusi pencegahan DBD secara alami dengan memanfaatkan bahan alam yang berada disekitar lingkungan dan menjelaskan bagaimana cara membuat spray anti nyamuk kepada ibu-ibu PKK desa Dlingo, Mojosongo, Boyolali. Segmen ketiga yaitu materi mengenai pengertian ABATE, spesifikasi ABATE, keuntungan, petunjuk penggunaan, dosis yang sesuai dalam penggunaan ABATE dan bahaya ABATE bila melebihi dosis. Pemaparan materi dilakukan dengan menayangkan materi menggunakan proyektor untuk memudahkan masyarakat dalam memahami materi.

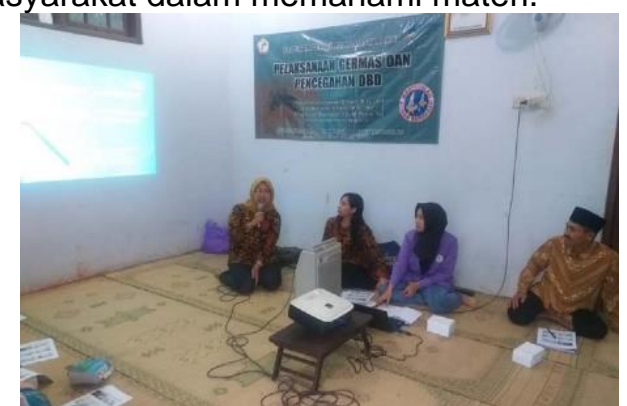

Gambar 1. Penyampaian materi penyuluhan

Materi-materi yang disampaikan beragam antara pembicara satu dengan yang lainnya sehingga dapat menambah pemahaman peserta yang mengikuti penyuluhan DBD. Acara sesi tanya jawab juga sangat aktif dikarenakan banyak masyarakat yang belum memahami betul mengenai DBD dan penanganannya. Peserta juga mendapatkan materi berbentuk hardfile agar mudah dibaca dan dipahami. Masyarakat yang mengikuti kegiatan sosialisasi mendapatkan brosur DBD yang berisikan ciri-ciri nyamuk DBD, gejala DBD dan pencegahan DBD, selain brosur juga dibagikan buku saku DBD yang berisikan tanaman apasaja yang dapat digunakan untuk mencegah DBD serta pengertian DBD, tanda gejala, pencegahan dan tempat berkembangbiak nyamuk DBD.

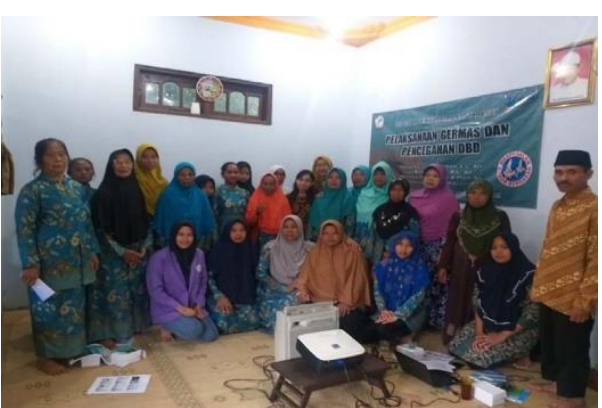

Gambar 2. Foto bersama peserta

Pada acara pengabdian ini juga dilakukan proses evaluasi terhadap tingkat kepuasan peserta kegiatan pengabdian yang dilaksanakan pada tema yang diambil. Hasil kuisioner menunjukkan 69,2\% peserta menyampaikan tema yang diambil baik sekali, $26,67 \%$ menyatakan baik dan 2,92\% menyatakan cukup. Hal ini menunjukkan tema yang diambil sangat menarik dan disukai peserta.

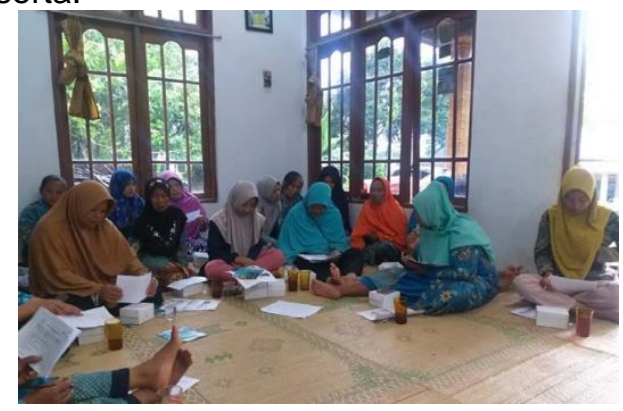

Gambar 3. Pelaksanaan evaluasi peserta

Evaluasi juga dilakukan pada peserta kegiatan pengabdian dengan mengerjakan prestest dan postest yang dilaksanakan terhadap tema yang diambil. Hasil pretest menunjukkan rata-rata nilai sebanyak 75 dan pada hasil nilai postest dengan rata-rata nilai sebanyak 100.

\section{SIMPULAN DAN SARAN}

Penyuluhan tentang tanda dan gejala DBD, solusi pencegahan DBD dan pemberantasan jentik nyamuk yang dilakukan di Desa Dlingo, Kecamatan Mojosongo, Kabupaten Boyolali dengan peserta ibu-ibu PKK berjumlah 31 orang berjalan dengan baik dan lancar. Program pengabdian yang telah dilaksanakan juga menunjukkan adanya peningkatan pemahaman peserta dilihat dari peningkatan rata-rata nilai pretest ke postest yaitu 75 ke 100. Peserta kegiatan juga menyatakan puas terhadap program pengabdian masyarakat ini, dari 31 peserta sebanyak $69,2 \%$ peserta menyatakan tema yang diambil baik sekali, 26,67\% menyatakan baik, dan $2,92 \%$ menyatakan cukup.

Pengabdian mengenai tanda, gejala serta upaya pencegahan dan penanggulangan 
DBD diharapkan dapat terus dilaksanakan di daerah-daerah lain mengingat hingga saat ini kasus DBD masih banyak ditemui di Indonesia.

\section{UCAPAN TERIMAKASIH}

Penulis mengucapkan terimakasih kepada Lembaga Penelitian dan Pengabdian STIKES Nasional yang telah mendanai pelaksanaan pengabdian masyarakat yang dilaksanakan pada bulan Maret 2020. Ucapan terima kasih juga kami ucapkan kepada Kepala Desa beserta segenap warga Dlingo, Mojosongo, Boyolali.

\section{DAFTAR RUJUKAN}

Candra, A. (2010). Demam Berdarah Dengue: Epidemiologi, Patogenesis, dan Faktor Risiko Penularan Dengue Hemorrhagic Fever : Epidemiology, Pathogenesis, and Its Transmission Risk Factors. Aspirator, 2(2), 110-119.

Dinas Kesehatan Kabupaten Boyolali. (2019). Profil Kesehatan Kabupaten Boyolali. Dinas Kesehatan Kabupaten Boyolali.

Kusuma, A. P., \& Sukendra, D. M. (2016). Analisis Spasial Kejadian Demam Berdarah Dengue Berdasarkan Kepadatan Penduduk. Unnes Journal of Public Health, 5(1), 48-56.

Lisiswanti, R., Angraini, D. I., Apriliana, E., \& Saputra, O. (2015). Peningkatan Pemahaman Masyarakat tentang Pencegahan Demam Berdarah di Kampung Baru. Jurnal JPM Ruwa Jurai, 1(1), 13-16.

Misnadiarly. (2009). Demam Berdarah Dengue (DBD): Ekstrak Daun Jambu Biji Bisa untuk Mengatasi DBD. Pustaka Populer Obor.

Muharni, S., Almahdy, \& Martini, R. D. (2013). Effect of the use of supplements Psidii folium extract (psidium guajava linn.) and red fermented rice (Monascus purpureus) in increase of thrombocytes at dengue hemorrhagic fever (DHF) science in the installation of disease in hospital dr. M. Djamil Padan. Penelitian Farmasi Indonesia, 1(2), 57-61. https://ejournal.unri.ac.id/index.php/FPFI/ article/view/1247

Prasetio, J. N. (2015). Potential Red Guava Juice in Patients With Dengue Hemorrhagic Fever. J Majority, 4(2), 2529.

Saptawati, L., Febrinasari, R. P., Yudhani, R. D., Yono, H., Faza, A. G., Luthfiani, S., Ummiyati, H. S., Sudiro, T. M., \& Dewi, B. E. (2017). In vitro study of eight Indonesian plants extracts as anti Dengue virus. Health Science Journal of Indonesia,
Volume 4, Nomor 2., April 2021.

p-ISSN : 2614-5251

e-ISSN : 2614-526X

$8(1)$,

$12-18$.

https://doi.org/10.22435/hsji.v8i1.6601.12 $-18$

Sukohar, A. (2014). Demam Berdarah Dengue (DBD). Medula, 2(2), 1-15. https://doi.org/10.35952/jik.v1i2.80

Tampi, F. H., Runtuwene, J., \& Pijoh, V. D. (2013). Survei Jentik Nyamuk Aedes spp di desa Teep Kecamatan Amurang Barat Kabupaten Minahasa Selatan. Jurnal EBiomedik, 1(1), 260-264. https://doi.org/10.35790/ebm.1.1.2013.43 56

Yulidar, \& Hadifah, Z. (2014). The Abormalities of Larvae's Morphology After Temefos Exposure in Phase Larvae Instar 3 (L3). Jurnal Buski, 5(1), 23-28. 